University of Nebraska - Lincoln

DigitalCommons@University of Nebraska - Lincoln

2001

The Pacific Island Mapping Program of the US Geological Survey

Frank C. Whitmore Jr.

Smithsonian Institution

Follow this and additional works at: https://digitalcommons.unl.edu/usgsstaffpub

Part of the Earth Sciences Commons

Whitmore, Frank C. Jr., "The Pacific Island Mapping Program of the US Geological Survey" (2001). USGS Staff -- Published Research. 230.

https://digitalcommons.unl.edu/usgsstaffpub/230

This Article is brought to you for free and open access by the US Geological Survey at DigitalCommons@University of Nebraska - Lincoln. It has been accepted for inclusion in USGS Staff -- Published Research by an authorized administrator of DigitalCommons@University of Nebraska - Lincoln. 


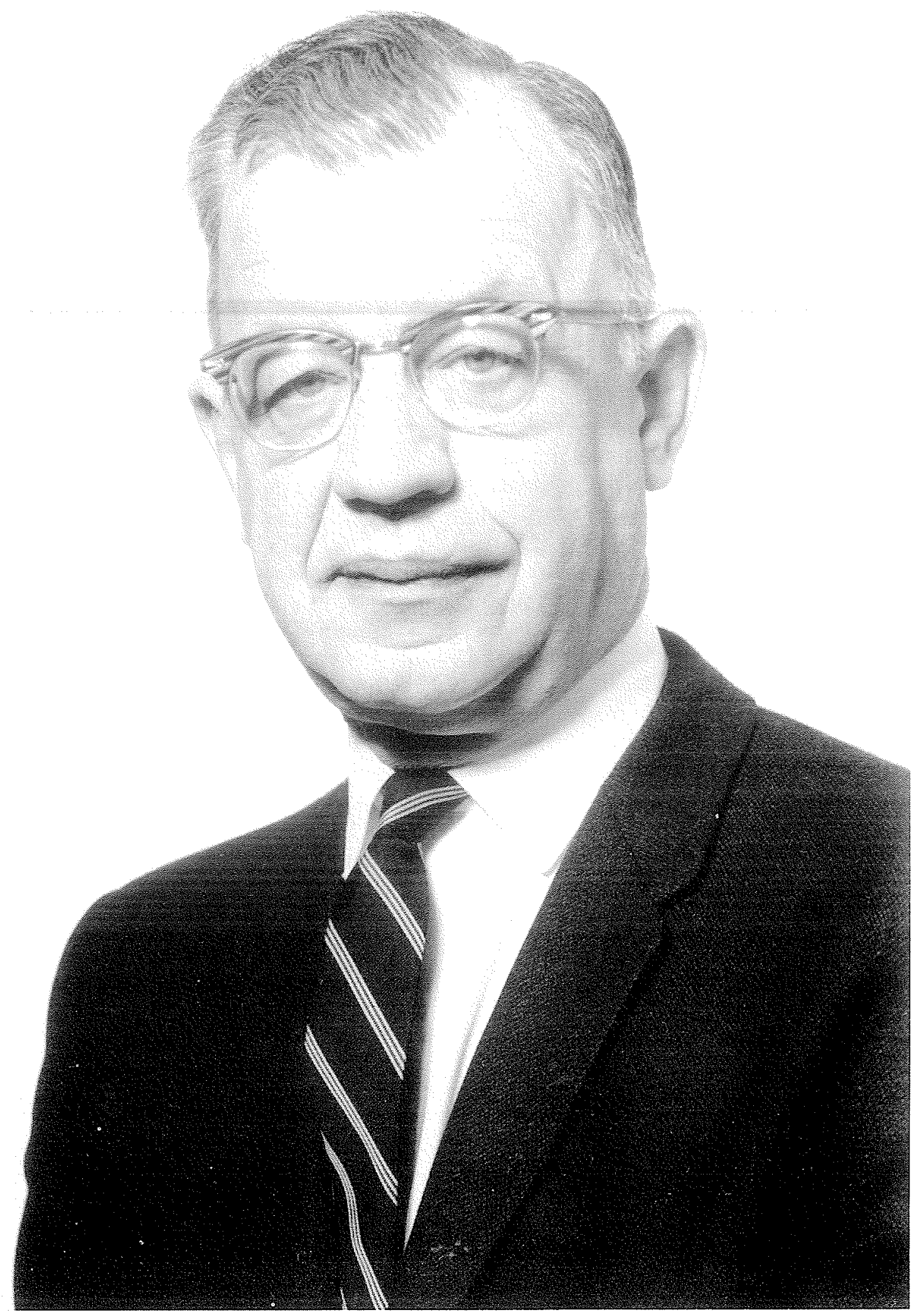

Frank C. Whitmore Jr. 1965 
The Atoll Research Bulletin 494 (December 2001). Issued by the Smithsonian Institution.

\title{
THE PACIFIC ISLAND MAPPING PROGRAM OF THE U.S. GEOLOGICAL SURVEY
}

\author{
BY
}

FRANK C. WHITMORE, JR.

A little-known aspect of the U.S. Geological Survey history is its involvement in preparing terrain intelligence reports during World War II. The Survey's Military Geology Unit was in charge of compiling these reports on areas of possible military operations. Maps were the main part of these studies; they were compiled from existing maps, geologic and soils literature, aerial and ground photographs, and travelers' accounts. Compiled geologic and soils maps served as basic data for interpretative maps on such subjects as construction materials, water supply, road and airfield siting and construction, and cross-country movement by tanks.

Many of the Strategic Engineering Studies, as these intelligence reports were called, dealt with islands in the western Pacific Ocean. In the course of preparing these, it became apparent that geologic, soils, and even topographic information on the islands was sparse. Furthermore, American engineers were not well informed about some aspects of the tropical environment, such as the behavior of laterite soil when disturbed by earth-moving equipment.

After the war, the Office of the Engineer, Far East Command, U.S. Army, was responsible for the construction and maintenance of bases in the western Pacific. Also, the United States had assumed responsibility for the Trust Territory of the Pacific Islands, including the Caroline, Gilbert, Marshall, and Palau Groups and the islands of Yap. Members of the U.S. Geological Survey, assigned to the occupation forces in Tokyo, were consulted about construction and water-supply problems in the islands.

The Army's continued interest in Pacific island geology coincided with a longcherished hope of Harry S. Ladd, who in 1946 was Assistant Chief Geologist of the USGS. In the 1920's Ladd, with J. Edward Hoffmeister, had mapped the geology of Fiji. Ladd, an invertebrate paleontologist, had become interested in the Tertiary

paleogeography of the Pacific Basin and in the origin and history of atolls; the latter was demonstrated in subsequent years by his involvement in deep drilling on Bikini and Eniwetok.

In 1945 Ladd conceived the idea of a long-term geologic mapping program in the islands of the western Pacific, and in January, 1946, he went to Tokyo to discuss the idea with officers of the Office of the Engineer, Far East Command. Their response was encouraging, and Ladd returned to Washington, where the approval of the Office of the

USGS Associate, Department of Paleobiology, National Museum of Natural History, Smithsonian Institution, Washington, DC 20560-0137

This article is a U.S. government work, and is not subject to copyright in the United States. 
Chief of Engineers was soon given. A mechanism for undertaking the program was available in the form of an agreement, reached in 1942, between the Corps of Engineers and the Geological Survey, that established the Military Geology Unit, to be supported by funds transferred from the Corps to the Survey.

It was agreed that the mapping would start with Okinawa in the spring of 1946. From the Army's point of view the choice was obvious: Okinawa was slated to continue as a major U.S. base in the western Pacific. Geologically, it was a difficult first step in a long-range program: it was large and extremely varied-from Tertiary sediments in the south to complex Paleozoics in the north. The beginnings of a logistic backup organization were present in Tokyo with the Office of the Engineer and a contingent of USGS geologists who comprised the Mining and Geology Division, Natural Resources Section, General Headquarters, Supreme Commander for the Allied Powers.

Thomas A. Hendricks of the U.S. Geological Survey was serving as Chief, Mining and Geology Division, Natural Resources Section. When the Pacific Island Mapping Program was approved, Hendricks published a notice in the U.S. Army Newspaper, Pacific Stars and Stripes, asking geologists in uniform to take their discharges in the Pacific Theatre and join the Okinawa mapping party as civilian members of the U.S. Geological Survey. Four did so. One of them, Gilbert Corwin, was already on Okinawa. The other three, Delos E. Flint, Raymond A. Saplis, and Warren Fuller, took their discharges from the service in Japan. McClelland G. Dings, an experienced USGS mapping geologist, was sent from Washington to become the first chief of the Okinawa field party.

My connection with the island mapping program began on July 1, 1946, when I became Geologist in Charge, Military Geology Unit, USGS. I had been serving in the Natural Resources Section in Tokyo, but in the spring of 1946 was on tempory duty with the XXIV Corps in Korea, where I carried out reconnaissance surveys of ports, railroads, and highways. When I was summoned from Korea to Washington for my new job, I faced the problem of the Okinawa party and of planning, staffing, and supporting other island mapping projects.

My preparation for the job of branch chief was unusual. I received the $\mathrm{Ph}$. D. in vertebrate paleontology from Harvard in 1942, with a minor in geomorphology. From 1942 to 1944 I was the one-man geology department at Rhode Island State College (now the University of Rhode Island). While there, I instituted a course in engineering geology. In 1944 I joined the Military Geology Unit, USGS, as an editor, and became chief editor of the Unit. In 1945 I was assigned to the Office of the Engineer, Southwest Pacific Area, in Manila, and in October, 1945 entered Tokyo with the occupation forces. There I located sand and gravel for extension of Japanese airfields and made a study of precious metal resources. My background was notable for a lack of mapping experience: my mapping was (and still is) limited to a brief field course while in graduate school. This deficiency was ameliorated by my two years' experience editing geologic maps. I was chief of the Military Geology Branch from 1946 to 1959, when I returned to paleontology with the Paleontology and Stratigraphy Branch, USGS, stationed at the National Museum of Natural History. There I have concentrated on the study of fossil whales. 
The island program was originally projected to take ten years; eventually it took about fifteen. The mission of the new program was far different from that of the Natural Resources Section, which was devoted to the inventory of Japanese minerals, soils, agriculture and fisheries as a basis for policy decisions aimed at putting the Japanese economy on a self-supporting level. The island mapping program, on the other hand, included not only the Ryukyu islands, which were eventually recognized as part of Japan proper, but also Guam, a U.S. possession, and, most extensive, the Trust Territory of the Pacific lslands, including the Mariana Islands other than Guam, the Marshall Islands, Caroline Islands, Yap, Gilbert Islands and Palau. It was therefore decided that a separate office would be established in Tokyo to oversee the island mapping program. This office, established in 1948, was placed in the Office of the Engineer, Far East Command, U.S. Army, rather than under General Headquarters, Supreme Commander for the Allied Powers. It was staffed by personnel of the U.S. Geological Survey. Sherman K. Neuschel (Fig. 1), a geologist with mapping experience in the Mineral Deposits Branch, USGS, was made chief of the Tokyo Office. The office functioned as a unit of the Army command in the Far East; its mapping program was initiated by the USGS, approved by the Engineer, Far East Command, and funded by the Office of the Chief of Engineers in Washington, DC.

The initial function of the Tokyo office was to

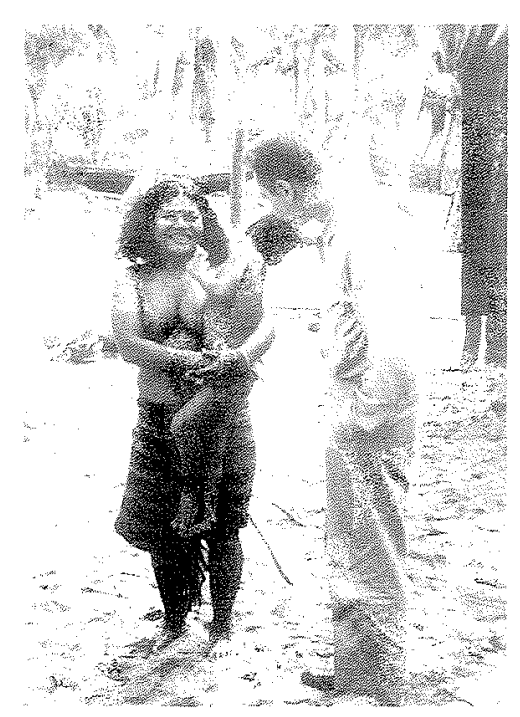

Figure 1. Sherman K. Neuschel talks to native of Yap Island, 1948. provide logistic support for the field parties. Field-party personnel were recruited by the Military Geology Branch, USGS, in Washington. They were then sent to Tokyo, where their travel within the Pacific area was arranged by the Army (Fig. 2). But as the program developed, the Tokyo office became much more than a staging area or travel agency.

As Chief of the Military Geology Branch (formerly the Military Geology Unit), I established a policy for our mapping programs: we would prepare maps and reports to meet the needs of military agencies, and at the same time we would publish fundamental scientific papers in the appropriate literature. Many of the scientific contributions were published as Professional Papers of the USGS; some of these were descriptions and analyses of the geology of the islands, while others were paleontologic monographs. The military geology reports were published in Tokyo by the Office of the Engineer, Far East Command. Each report included a geologic map and a soils map, with accompanying text. These were followed by interpretative sections, each with one or more maps: engineering geology, including construction materials, foundation conditions, road construction and maintenance, and airfield siting; water supply, terrain analysis, including suitability for cross-country movement by tracked vehicles, and landing beaches. A list of military reports on Pacific islands was published as Appendix 2 by Corwin (1998); Bonham (1997) compiled a list of all publications, both military and scientific, of the Military 


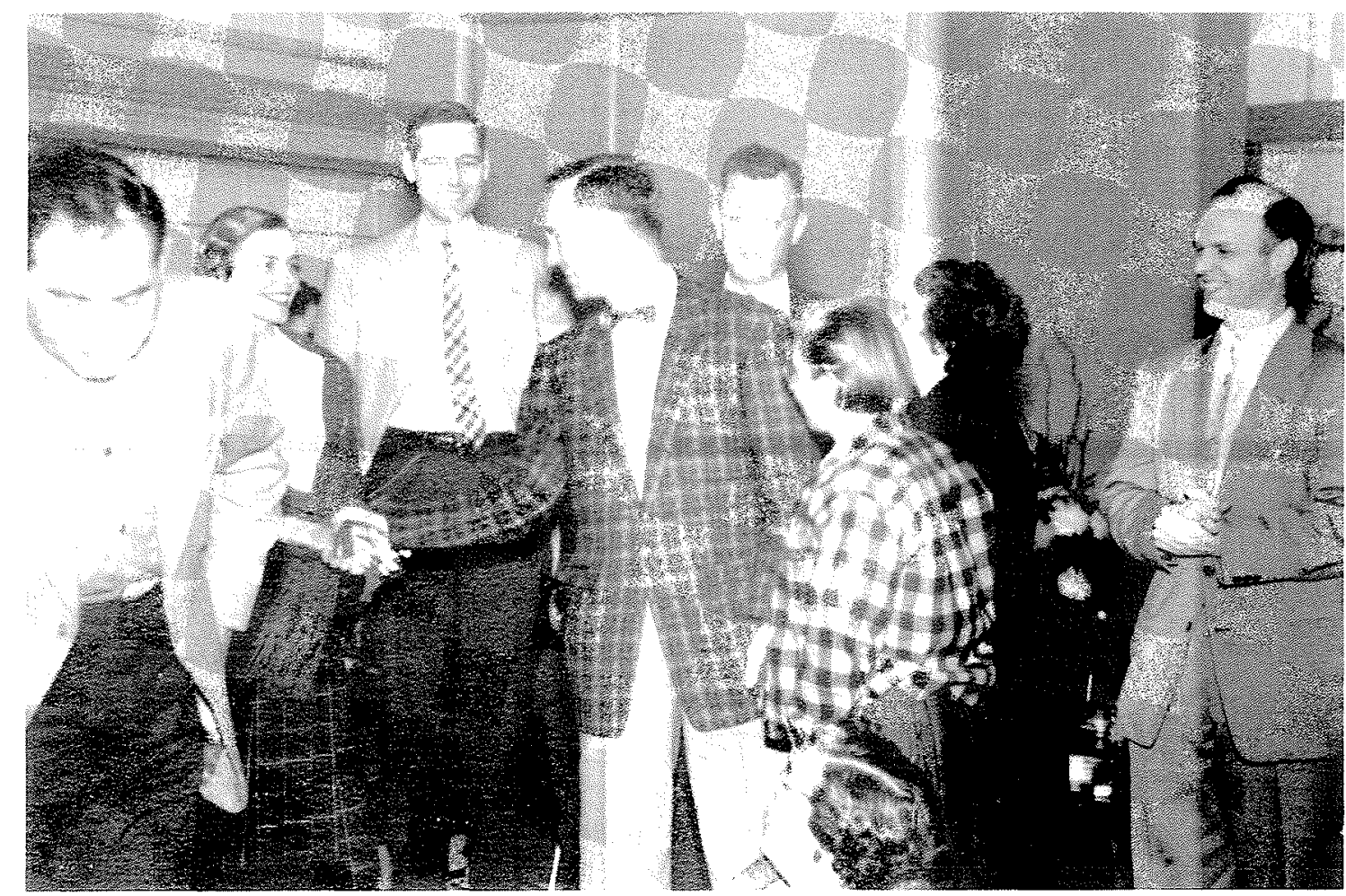

Figure 2. New recruit being welcomed to the Tokyo office. David B. Doan (3rd from left), Frank C. Whitmore (5th from left), Helen L. Foster (6th from left), Gilbert Corwin (far right).

Geology Branch.

In deciding which islands to map, the main criterion was diversity, a consideration that met both military and scientific needs. As far as I know, there was never any consideration of strategic importance in choosing islands to be mapped; I think that MacArthur's march across the Pacific, including many unlikely atoll battlegrounds, was too fresh in our memories to allow us to attempt prediction of the course of future operations. So we chose island types: high complex islands such as Okinawa, which contains some Paleozoic rocks and which we now know to be related to continental plates; other high islands of more oceanic nature and with a heavy volcanic component, such as the Marianas; and then the series illustrating Darwin's theory of atoll formation, from the cone of Ponape (which was not mapped) to the sunken caldera of Truk to the atolls of the Marshalls. The list of islands to be mapped was made by the Military Geology Branch, and as far as I can remember our recommendations were always accepted by the Corps of Engineers.

It is not the purpose of this paper to present a chronologic account of the mapping of the islands; this can be gleaned from Corwin, 1998. Rather, I wish to discuss the organization of the work, how it was undertaken, and how its philosophy evolved as the work went on.

In 1948 and the years immediately following, it was hard to hire young geologists for work abroad at government salaries. Most young men had just gotten out of the armed services and had already seen enough of the world; many had gone back to 
school under the G.I. Bill. And the oil companies were hiring at salaries far higher than the government could offer.

USGS geologists sent overseas during the war and the occupation of Japan had been on six-month assignments, although these were sometimes extended to as much as a year. This policy was followed during the first few years of the island mapping program, and it was soon obvious that the arrangement was inefficient. Most of the geologists, although well trained, were not experienced in mapping; furthermore, in islands of continental aspect such as the Ryukyus and Marianas, comparisons had to be made with Japan, Taiwan, and the well established Dutch East Indies Tertiary section. So even with a full complement, mapping went more slowly than planned. Also, the personnel supply line was long and slow: geologists were hired by the Branch Chief's office in Washington, sent to Tokyo on military orders, indoctrinated there and, after receiving Pacific Theater orders, flown to the island of their assignment. Corwin (1998) gives a pathetic picture of what it was like on Palau between the departure of one contingent and the arrival of the next.

Okinawa and Palau, the earliest projects, suffered from incomplete staffing. The Okinawa project took three years to complete and had three party chiefs. The Saipan operation (September, 1948 - August, 1949) was a turning point; under the dynamic leadership of Preston E. Cloud, Jr., it produced a military geology report and a voluminous Professional Paper (Cloud et al.). By the early 1950's, recruiting and logistic arangements had improved to the point where field parties were fully staffed. Guam, Pagan, Ishigaki, Miyako and Truk were mapped by geologists most of whom stayed through the entire period of the field work, and a reconnaissance was carried out in the atolls of the Marshall Islands.

As the program progressed, the size of the Tokyo office increased. The office expedited the flow of people and supplies to and between the islands. Much of the existing geologic literature concerning the islands was in Japanese, so a translating office was established, staffed by Japanese geologists hired by the U.S. Army. A staff of Japanese draftsmen, supervised by a USGS cartographer, drafted the maps for the military geology reports, and editors sent from the USGS edited the text. In addition to geology, soil science was deemed important in the program because of its application to military operations, especially cross-country movement by tracked vehicles. Two senior soil scientists from the U.S. Department of Agriculture served six-month stints with the Okinawa party, and one served the entire term of the Guam party. Younger soil scientists also served on Okinawa and other islands. A hydrologist conducted extensive mapping on Guam. An engineering geologist visited almost every island to help the geologists in preparing the applied geology maps, on which units were defined according to engineering properties rather than geologic age. F. Raymond Fosberg, a world-famous authority on Pacific botany, served as a consultant to most of the island mapping parties, making vegetation maps and adding to his already huge herbarium at the United States National Museum of Natural History. Fosberg worked for the Military Geology Branch (MGB) under an informal (and unwritten) arrangement worked out between us. Each year, MGB was commited to submit terrain analyses of six countries to the Engineer Intelligence Division in Washington. Each report included a vegetation map. Ray 
6

prepared the vegetation maps and worked as needed for the island mapping program. If there was any time left over (and there usually was, for Ray was a fast worker), Ray was free to do whatever he wished if he could raise the money to support his field work.

lt was necessary to correlate Tertiary strata of the various islands, which led to dependence on paleontology and to the organization of a cadre of specialists on fossil mollusks, corals, foraminifera, diatoms, and other organisms. These specialists, mostly at universities, were hired by the USGS on a WAE (when actually employed) basis, which allowed payment for part-time work. Thus information could go directly to parties in the field. Many USGS Professional Papers resulted from this work, and some paleontologists visited the field parties.

\section{CONCLUSIONS}

Without the logistic support of the U.S. Army, the Pacific Island Mapping Program would have been at best difficult, and probably impossible. This cooperation between science and the military has a long tardition: the voyage of the Beagle, the Discovery expedition co-sponsored by the Royal Society of London, the American Wilkes Expedition, and the Wheeler Survey of the mid-nineteenth century in the western United States are some examples.

Many of the geologists in the program, although well trained, had little or no previous experience in geologic mapping. Chiefs of early parties, although they served short terms in the islands, were crucial in establishing mapping procedures and in training the younger men. On Okinawa, McClelland Dings was succeeded by F. Stearns MacNeil, an experienced Tertiary stratigrapher, who also served for a short time. MacNeil was succeeded by Delos E. Flint, a Caltech graduate who had mapped for the USGS in Cuba. Flint remained in charge of the project until its completion. On later projects, experienced geologists were assigned as party chiefs for the full period of the project: Preston E. Cloud, Jr. on Saipan, Joshua 1. Tracey, Jr. on Guam (Fig. 3), and John Stark on Truk. An important part was played by Charles G. Johnson, an experienced groundwater geologist who served through the entire program. He mapped Yap singlehanded, monitored many island projects, and eventually succeeded Neuschel as head of the Tokyo office. Toward the end of the program David B. Doan, who had been trained on Guam, was party chief on Miyako in the Ryukyu Islands. Helen L. Foster, a Ph. D. from the University of Michigan who had worked in the Tokyo offce compiling a massive bibliography of Pacific Island geology, became party chief on Ishigaki, also in the Ryukyus. Gilbert Corwin (Fig. 4), who had mapped on Okinawa and been party chief on Palau, was named party chief for Pagan, a volcanic island in the Marianas. This project, which came late in the program, was unique in that, of its four members, two had extensive experience in preparing terrain intelligence reports in the Military Geology Branch. One was Lawrence D. Bonham, who later became chief of the branch; the other was Maurice J. Terman, who had spent several years preparing trafficability maps of Europe in the MGB office in Heidelberg, Germany.

The Pagan report was much larger than would have been expected from such a small island. This was because of more detailed analysis of the military engineering 


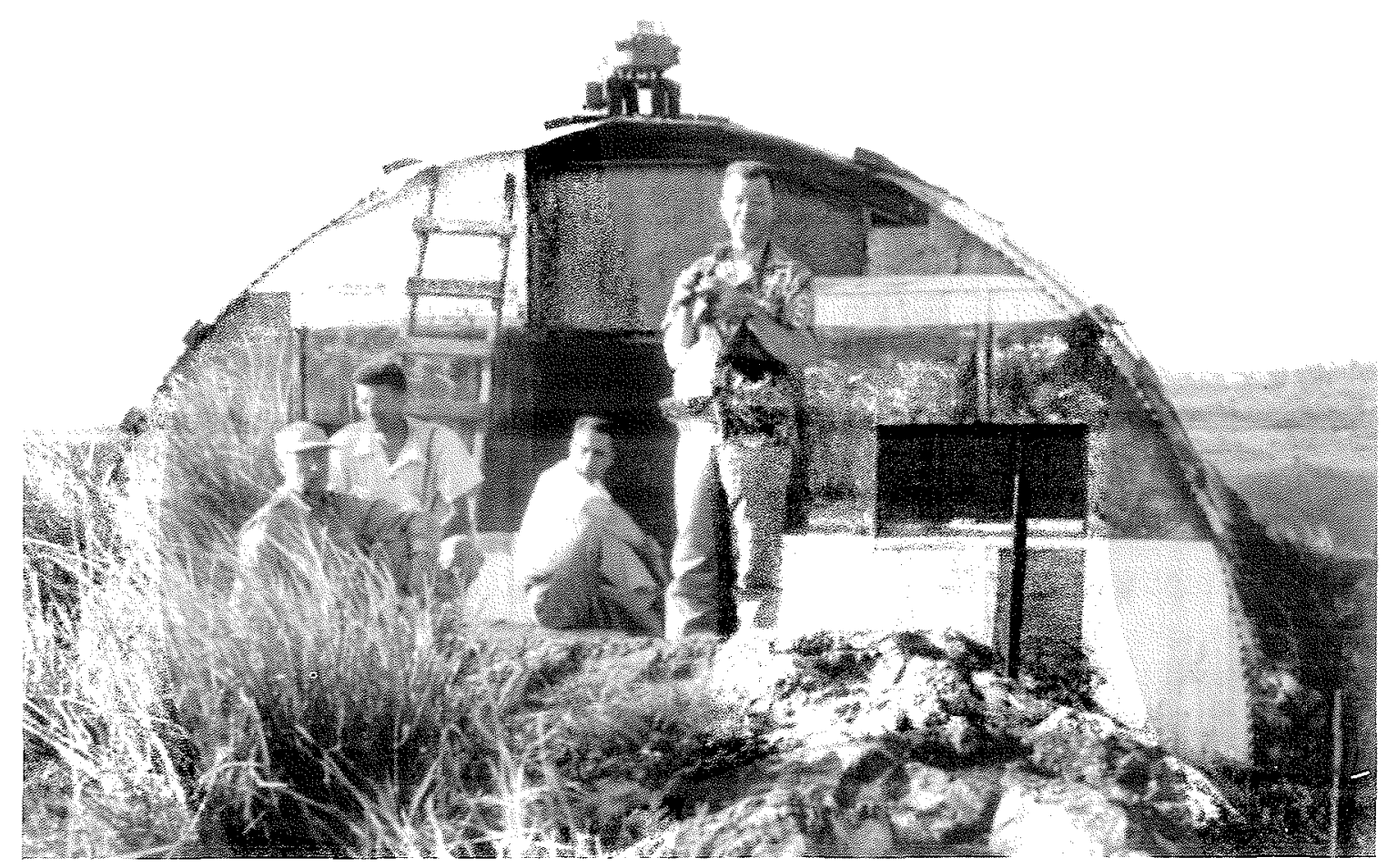

Figure 3. Members of the Tokyo office make a field visit. Mt. Alutom, Guam, 1952.

Left to right: Harold May, Joshua I. Tracey (Guam party chief), Sherman K. Neuschel (Chief, Tokyo Office), and Frank C. Whitnore (Chief, Military Geology Branch).

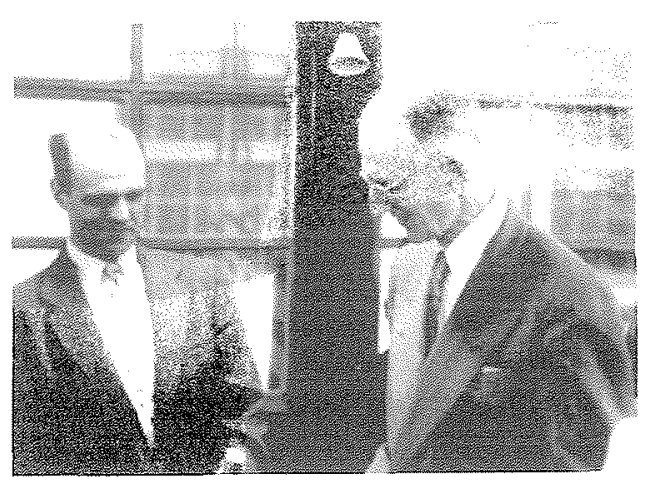

Figure 4. Gilbert Corwin (left) confers with Carl Stensland (soil scientist), Tokyo, 1956. properties of the surficial deposits of the island, making this study a useful precursor for later terrain analyses.

A unifying factor in the program was the USGS tradition of geologic mapping - an art that is hard to reduce to the written word. It is taught in the field, and chief among many complex components of the technique is an awareness of scale, which governs the definition of map units, both for basic geology and for applied subjects such as location of construction materials. Most mapping was at scales of $1: 25,000$ or $1: 50,000$, depending on the size of the island. These large scales allowed separation of map units which would have to be lumped together at smaller scales. This multiplication of map units, together with heavy vegetative cover, slowed the field work.

The soil scientists did not have the benefit of the world-recognized time-rock classification available to geologists. In the United States, the Division of Soil Survey, U.S. Department of Agriculture, had gone to great pains to erect a soil-classification system with the catchy title The Seventh Approximation, but in foreign areas with 


\section{8}

tropical soils the U.S. classification had to be extended. Even in the United States, when mapping of a new area began, a senior soils correlator would go first and set up a map legend for mappers to follow. This system was followed on the major Pacific islands: Edwin Templin, a senior soils correlator, set up the map legend for Okinawa and consulted on the soils mapping of other islands, and Roy Simonson, later assistant chief of the Soil Survey, also participated in the Okinawa mapping, to be followed by more junior soil scientists who finished the work and went on to map on other islands.

Although, as mentioned above, a philosophy of mapping and publication governed the program, there was never tight control as to how an island should be mapped. This control was left in the hands of the party chief, and there is no doubt that the interests and experience of these geologists affected the end product so that. although the military geology reports look uniform, they probably differed in ways that would be apparent to the geologists if not to the engineers. The military engineering maps were probably more uniform than were the geology and soils maps, because many of them were designed with the help of Allen $\mathrm{H}$. Nicol, an engineering geologist who visited most of the island parties. The progress of mapping projects was monitored by means of visits by S.K. Neuschel, the chief of the mapping program, who headed the Tokyo office, and occasionally by the chief of the Military Geology Branch from Washington.

For the younger members of the program, the island mapping was a sort of graduate school. Most of them lacked advanced degrees; a young man who spent several years on an island would come home pretty well heeled, and many used their money to attend graduate school. For some, the experience instilled an interest in a specific geologic speciality. Two outstanding examples can be noted. Richard L. Hay, now a professor at the University of Illinois, was assigned as a Corps of Engineers private to the Truk Party under John Stark. There he began the interest in volcanic stratigraphy that led to his unravelling the stratigraphy of Olduvai Gorge and dating the famous hominid footprints at Laetoli. The late Seymour O. Schlanger, who at his death was professor at Northwestern University, began an interest in limestone petrology on Guam, and extended his work to global consideration of oceanic sedimentation.

Since the end of the Pacific Island Mapping Program, the theory of plate tectonics has revolutionized geology. Despite this, the program has bequeathed a

database that will remain useful. Possibly this usefulness results from the pragmatic aim of the work, which encouraged the objectivity of direct observation, with little of the bias that comes with theoretical preconceptions. Perhaps work of this sort can be called exploration, in contrast to the analysis that will follow, for there was no effort to synthesize the results of the program. In light of subsequent developments in geology, this was probably just as well.

\section{REFERENCES}

Bonham, S.M.

1997. Reports and maps of the Military Geology Unit, 1942-75: USGS Open File Report 97-175, 135 pages. 
Cloud, P.E., Jr., R.G. Schmidt and H.W. Burke

1956. Geology of Saipan, Mariana Islands. Part 1. General geology. U.S. Geological Survey Professional Paper 280-A. $126 \mathrm{pp}$.

Corwin, Gilbert

1998. Engineer intelligence and the Pacific Geologic Mapping Program: Pages 67-74

in J.L. Underwood, Jr. and Peter L. Guth, eds., Military Geology in War and

Peace. Geological Society of America, Reviews in Engineering Geology, Vol. XIII. 